\title{
An immunohistochemical study and review of potential markers of human intestinal $M$ cells
}

\author{
N.A.C.S. Wong*, M. Herriot*, F. Rae \\ Department of Pathology, University of Edinburgh, Medical School, Edinburgh, UK
}

(C)2003, European Journal of Histochemistry

M cells are found in intestinal follicle associated epithelium. Studies into the physiological and pathological roles of human $M$ cells have been hampered by the lack of well-substantiated, specific markers for these cells. A critical literature review suggests the following molecules may potentially serve as such markers: CK7, FcaR (CD89), S100, CD1a, CD21, CD23, sialyl Lewis A, and cathepsin E. Normal ileum, appendix and colorectum were studied using paraffinembedded, formalin-fixed tissue and immunohistochemistry for these 8 markers. Cathepsin E immunohistochemistry was also performed on cases of colorectal adenocarcinoma, colorectal adenoma, colorectal hyperplastic/metaplastic polyp, lymphocytic colitis, collagenous colitis, pseudomembranous colitis and active ulcerative colitis. Of the 8 markers tested, only cathepsin E appeared to be specific to follicle associated epithelium (expressed by cells with and without $M$ cell morphology) and follicular crypt epithelium; this specificity was limited to the colorectum. Focal epithelial expression of cathepsin $\mathrm{E}$ was seen in adenocarcinoma, adenoma, hyperplastic/metaplastic polyp, ulcerative colitis and pseudomembranous colitis. In conclusion, cathepsin $\mathrm{E}$ is a specific marker of normal colorectal follicle associated epithelium and follicular crypt epithelium though is not specific to $\mathrm{M}$ cells within these compartments. None of the other 7 markers studied is exclusively expressed by human $M$ cells.

*These authors have contributed equally to this work.

Correspondence: Dr. NACS Wong, Cancer Research UK Cancer and Immunogenetics Laboratory, Weatherall Institute of Molecular Medicine, John Radcliffe Hospital, Headley Way, Oxford OX3 9DS. Phone: 01865-222432. Fax: 01865222431; E-mail: newton.wong@cancer.org.uk

Key words: M cells, human, gastrointestinal tract, immunohistochemistry, cathepsin E.

Paper accepted on January 7, 2003

European Journal of Histochemistry 2003; vol. 47 issue 2 [Apr-Jun]:143-150
$\mathrm{M}$ cells ('membranous' or 'microfold' cells) are specialised epithelial cells normally found in the epithelium (so called follicle associated epithelium) overlying intestinal mucosal lymphoid follicles (Neutra 1998, Jepson et al. 1998, Nicoletti 2000). Such lymphoid follicles and, hence, $\mathrm{M}$ cells are particularly common in the ileum and appendix but are also found in the colorectum (Neutra 1998, Jepson et al. 1998, Nicoletti 2000). Compared with normal enterocytes and colonocytes, M cells show a handful of distinct morphological features. First, M cells possess a less well developed apical brush border with shorter microvilli and reduced expression of brush border associated proteins (Neutra 1998, Jepson et al. 1998, Nicoletti 2000). Second, M cells often show basolateral indentations or 'pockets' which contain lymphocytes of $T$ and/or B cell type (Neutra 1998, Jepson et al. 1998, Nicoletti 2000). These morphological features are in keeping with the principal function of $M$ cells known so far, namely transportation of antigens and microbes across intestinal epithelium (Neutra 1998, Jepson et al. 1998). Much, however, remains to be learnt about the role of human M cells in physiological and pathological states. In particular, it has been suggested that M cells represent the entry point of prion proteins from the intestinal lumen (Shmakov et al.2001) and that a unique subtype of colorectal carcinoma arises from follicle associated epithelium (Jass et al. 2000).

Attempts at extending our knowledge of human M cell function and pathology have, in part, been hampered by the lack of a specific marker for such cells. There have been attempts to apply $\mathrm{M}$ cell markers of other species to human tissue. However, it is well recognised now that there is wide variation in marker expression between $\mathrm{M}$ cells of different species and even between $\mathrm{M}$ cells at different sites within the same species. Markers that have been tested so far (reviewed in Table 1) may be divided into 4 main 
Table 1. Review of previously tested or potential markers of human intestinal M cells.

\begin{tabular}{|c|c|c|c|}
\hline Marker & Data suggesting possible use as a human $M$ cell marker & Limitation(s) to use in human tissue & References \\
\hline \multicolumn{4}{|l|}{ Filament proteins } \\
\hline Cytokeratin 8 & Specific to rat small intestinal (SI) M cells & Expressed by normal human colonocytes and enterocytes & $\begin{array}{l}\text { Rautenberg et al. 1996, } \\
\text { Kucharzik et al. } 1998\end{array}$ \\
\hline Cytokeratin 18 & Specific to pig SI M cells & Expressed by normal human colonocytes and enterocytes & $\begin{array}{l}\text { Gerbert et al. 1994, } \\
\text { Kucharzik et al. } 1998\end{array}$ \\
\hline Villin & $\begin{array}{l}\text { Cytoplasmic expression in mouse M cells compared } \\
\text { with membranous in enterocytes }\end{array}$ & $\begin{array}{l}\text { Occasional diffuse cytoplasmic expression seen in } \\
\text { human colonocytes and enterocytes }\end{array}$ & $\begin{array}{l}\text { West et al. 1988, } \\
\text { Kerneis et al. } 1996\end{array}$ \\
\hline Vimentin & Specific to rabbit appendix M cells & Not expressed by human $\mathrm{M}$ cells & Jepson et al. 1992 \\
\hline \multicolumn{4}{|l|}{ Lectins/glycoproteins } \\
\hline Sialyl Lewis A & $\begin{array}{l}\text { Apical membranous staining exclusive to human SI } \\
\text { and large intestinal (LI) M cells }\end{array}$ & $\begin{array}{l}\text { Only one previous study showing exclusive expression } \\
\text { Human appendix M cells not studied }\end{array}$ & Giannasca et al. 1999 \\
\hline Ulex (UEA-1) & Specific to mouse SI M cells & Expressed by human enterocytes & $\begin{array}{l}\text { Clark et al. 1993, } \\
\text { Giannasca et al. } 1999\end{array}$ \\
\hline \multicolumn{4}{|l|}{ IgA-related } \\
\hline Asialoglycoprotein receptor & Binds to human IgA & Expressed by rat enterocytes and human colorectal cells & Mu et al. 1997 \\
\hline Macrophage FcR & Binds to human IgA & Not expressed by human $\mathrm{M}$ cells & Weltzin et al. 1989 \\
\hline Neonatal rat jejunum IgR & Binds to human IgA & Not expressed by human $\mathrm{M}$ cells & Weltzin et al. 1989 \\
\hline Polymeric lgG & Binds to human IgA & Not expressed by human M cells & Weltzin et al. 1989 \\
\hline \multicolumn{4}{|l|}{ Other immunology-related } \\
\hline b1 integrin & Apical membranous expression in $M$ cells versus & Subtle difference in membranous localisation likely to & Clark et al. 1998 \\
\hline & $\begin{array}{l}\text { basolateral membranous expression in enterocytes } \\
\text { and colonocytes }\end{array}$ & $\begin{array}{l}\text { preclude use for functional and in vitro studies and } \\
\text { studies of neoplasms }\end{array}$ & \\
\hline Cathepsin E & Exclusive to human $\mathrm{SI}, \mathrm{LI}$ and appendix M cells & Only one previous study showing exclusive expression & Finzi et al. 1993 \\
\hline HLA-DR & Expressed by human SI M cells & Expressed by human enterocytes & $\begin{array}{l}\text { Spencer et al. } 1986 \text {, } \\
\text { Nagura et al. } 1991\end{array}$ \\
\hline Interleukin-1 & $\begin{array}{l}\text { Expressed by rabbit M cells in vitro after } \\
\text { stimulation with LPS }\end{array}$ & $\begin{array}{l}\text { Low baseline expression in unstimulated rabbit M cells } \\
\text { Expressed by human enterocytes and colonocytes }\end{array}$ & $\begin{array}{l}\text { Pappo et al. } 1993 \text {, } \\
\text { Jarry et al. } 1999\end{array}$ \\
\hline ICAM-1 & $\begin{array}{l}\text { Upregulated expression in in vitro model for human } \\
\text { M cells }\end{array}$ & Expressed by human colonocytes & $\begin{array}{l}\text { Maurer et al. 1998, } \\
\text { Gullberg et al. } 2000\end{array}$ \\
\hline VCAM-1 & $\begin{array}{l}\text { Upregulated expression in in vitro model for human } \\
\text { M cells }\end{array}$ & Expression (weak) by human colonocytes & $\begin{array}{l}\text { Maurer et al. } 1998 \text {, } \\
\text { Gullberg et al. } 2000\end{array}$ \\
\hline
\end{tabular}

groups: i) those related to cytosolic filaments; ii) those related to glycoproteins; iii) those related to the ability of M cells to bind IgA; and iv) a more heterogeneous group related to the cells' interactions with lymphocytes. Of these previous attempts to characterise a human $\mathrm{M}$ cell specific marker, the most promising involve sialyl Lewis A and cathep$\sin E$, an aspartic proteinase potentially involved in antigen processing and presentation (Bennet et al. 1992). However, in each case, the positive results have been presented in only one paper and have not been confirmed since (Finzi et al. 1993, Giannasca et al. 1999).

A review of $M$ cell features and putative functions compared with those of enterocytes and colonocytes suggests other molecules that deserve investigation as possible $\mathrm{M}$ cell markers. Cytokeratin 7 (CK7) is one such molecule based on the specificity of certain cytokeratin subtypes to M cells in various species (see Table 1) and the lack of CK7 expression by normal enterocytes and colonocytes (Osborn et al. 1986). A previous study suggested CK7 was not expressed by human $M$ cells (Kucharzik et al. 1998) but only appendiceal tissue was analysed. Further, preliminary studies in our laboratory have shown focal but unequivocal expression of CK7 in the follicle associated epithelium of human appendices. FcaR (CD89) shows 
Table 2. Specific details of immunohistochemistry protocols for markers studied. Otherwise, a common protocol was used for all the markers, as described in the main text.

\begin{tabular}{|c|c|c|c|c|}
\hline Marker & Antibody clone & Commercial source & Primary antibody concentration (duration) & Antigen retrieval (duration) \\
\hline CA19-9 & C241:5:1:4 & Novocastra, Newcastle, UK & $1: 200$ (45 min) & Citrate buffer pH 6.0 / pressure cooking (4 min) \\
\hline Cathepsin E & polyclonal (N19) & Santa Cruz, Santa Cruz, USA & $1: 100$ (30 min) & EDTA pH 8.0 / microwave (15 min) \\
\hline CD1a & NA $1 / 34$ & Dako, Ely, UK & $1: 10$ (45 min) & EDTA pH 8.0 / microwave (15 min) \\
\hline CD21 & IF8 & Dako, Ely, UK & $1: 10$ (30 min) & EDTA pH 8.0 / microwave (15 min) \\
\hline CD23 & MHM6 & Dako, Ely, UK & $1: 20$ (30 min) & EDTA pH 8.0 / microwave (15 min) \\
\hline Cytokeratin 7 & OV-TL 12/30 & Dako, Ely, UK & $1: 20(30 \mathrm{~min})$ & Citrate buffer pH 6.0 / microwave (15 min) \\
\hline FcaR & MIP-8a & Serotec, Kidlington, UK & $1: 90$ (30 min) & Dako TRS fluid / pressure cooking (4 min) \\
\hline S100 & polyclonal & Dako, Ely, UK & $1: 20$ (30 min) & None \\
\hline
\end{tabular}

specific binding to IgA (Morton et al. 1996) and while its expression was not demonstrated in a colorectal carcinoma cell line (Kitamura et al. 2000), such expression has not been looked for amongst normal enterocytes and colonocytes and certainly not amongst $M$ cells. Finally, in view of possible roles for $\mathrm{M}$ cells in antigen processing and presentation (Neutra 1998), it may be hypothesised that the cells express similar molecules to certain antigen presenting cells, e.g. S100 and CDla (as expressed by Langerhans cells) and CD21 and CD23 (as expressed by follicular dendritic cells). The aims of this study were, therefore, to 1 ) investigate whether FcaR, S100, CD1a, CD21 and CD23 may serve as specific markers for human intestinal $\mathrm{M}$ cells; and 2) to retest the hypotheses that CK7, sialyl Lewis A and cathepsin E represent such markers.

\section{Materials and Methods}

Paraffin-embedded, formalin-fixed blocks were collected from the following human tissues: terminal ileum (10 cases), appendix (10 cases), and colorectum ( 5 cases from right colon and 5 cases from left colon/rectum). These cases had been selected because haematoxylin and eosin-stained sections of all cases (reviewed by NW) were normal. All cases represented surgical resection specimens. When collected from specimens containing neoplasia, only tissue at a distance from the neoplasm was chosen. For cathepsin E immunohistochemistry (see below), paraffin-embedded, formalin-fixed blocks were also collected from cases of the following human colorectal diseases: adenocarcinoma ( 3 microsatellite unstable and 3 microsatellite stable cases), adenoma (8 cases), hyperplastic/metaplastic polyp (5 cases), collagenous colitis
(5 cases), pseudomembranous colitis (5 cases), active ulcerative colitis ( 5 cases) and lymphocytic colitis (5 cases). Study of the above, anonymised tissues was carried out in accordance with guidelines of the Lothian Local Research Ethics Committee.

Three $\mu \mathrm{m}$ thick sections were cut from the tissue blocks and used for immunohistochemistry. The monoclonal antibody CA19-9 is targeted against sialyl Lewis A (Allen et al. 1987, Shimono et al. 1994). Being widely available and having been extensively used in previous immunohistochemical studies of human intestine (Allen et al. 1987, Shimono et al. 1994), CA19-9 was chosen to study expression of this glycoprotein. Specific details of the immunohistochemical protocols used for the markers studied are shown in Table 2. All tissue sections for immunohistochemistry were dewaxed and rehydrated, and then subjected to antigen retrieval, except for S100. Endogenous peroxidase was then blocked with $1 \%$ hydrogen peroxide in methanol (10 min), and endogenous avidin/biotin blocked (15 min each for each blocking fluid) using the Vector A/B Blocking Kit (Vector Laboratories, Peterborough, UK). Following incubation with primary antibody (Table 2) diluted in a commercial antibody diluent (Dako, Ely, UK), the sections were incubated for 30 minutes with biotinylated secondary antibody diluted in commercial antibody diluent (Dako): for cathepsin E, rabbit anti-goat antibody (Dako) at a 1:500 concentration; for S100, swine anti-rabbit antibody (Dako) at a 1:500 concentration; and for all others, rabbit anti-mouse antibody (Dako) at a 1:400 concentration. Visualisation was achieved using commercial ABC (Vector, 30 minutes) and DAB reagents (Dako, 5 minutes) with Mayer's haematoxylin as a counterstain. Normal 

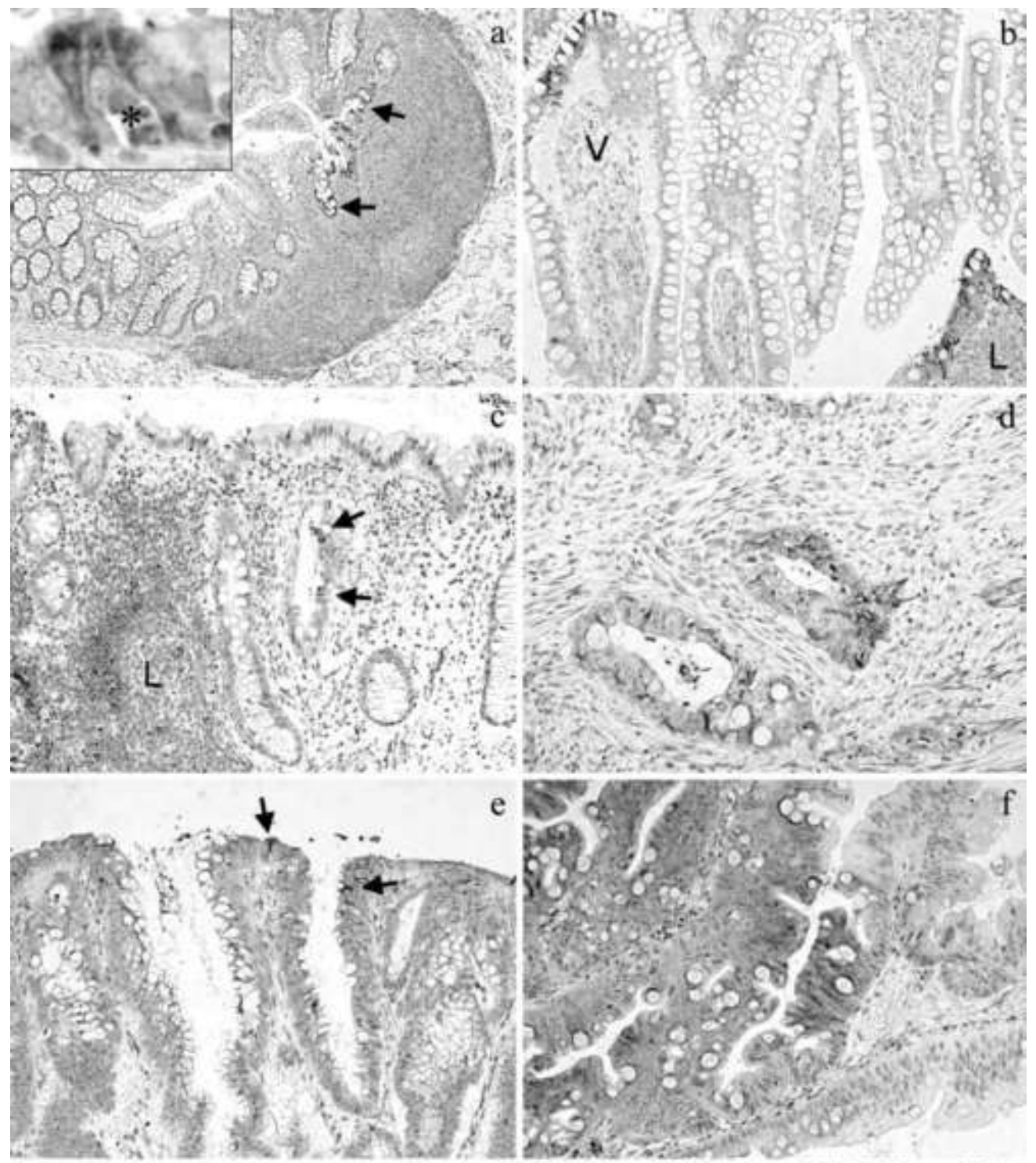

e
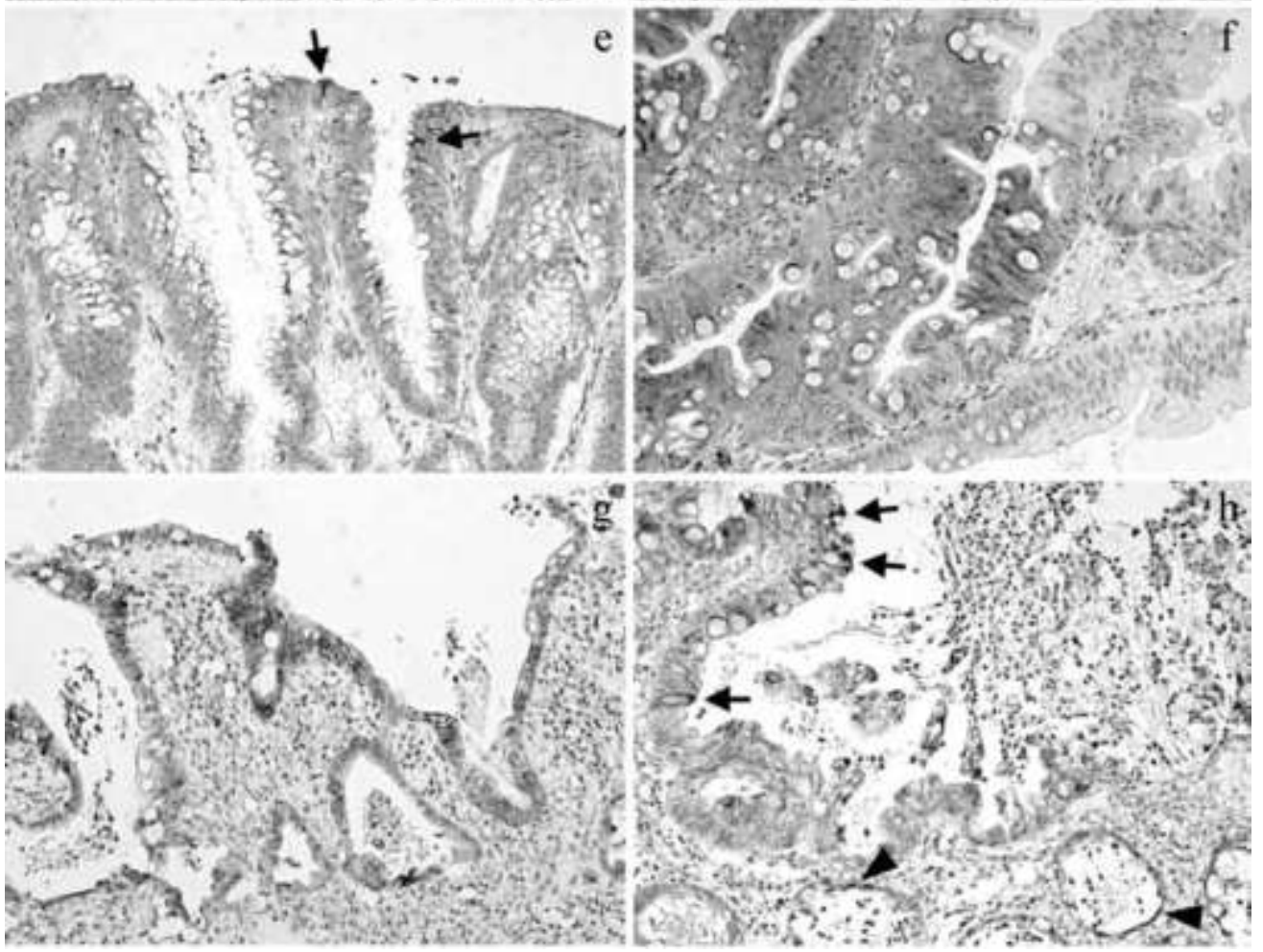

Figure 1. Examples of cathepsin E immunohistochemistry. a) The normal colon shows expression in follicle associated epithelium and in follicular crypt epithelium (arrowed, $x 5 \mathrm{obj}$ ). A higher power view (inset) shows cytoplasmic expression in at least one cell with unequivocal $\mathrm{M}$ cell morphology; a basolateral 'pocket' containing lymphocytes is marked with the asterisk ( $\mathrm{x} 40$ obj). b) Normal terminal ileum showed staining of epithelium overlying lymphoid follicles (L) but also occasional staining of villous (V) tip epithelium at a distance from follicles (x10 obj). c) Expression was seen in scattered crypt epithelial cells distant from appendiceal lymphoid follicles (L) (x10 obj). Expression was also demonstrated: in d) colorectal adenocarcinoma (x20 obj); e) colorectal adenoma, particularly in the superficial epithelium (arrowed, x10 obj); and f) colorectal hyperplastic/metaplastic polyp (more widespread cytoplasmic staining of varying intensity in left half of picture, $x 10 \mathrm{obj}$ ). g) Focal expression was seen both in surface and crypt epithelium in active ulcerative colitis (x10 obj). h) In pseudomembranous colitis (luminal 'summit' lesion shown in right side of picture), staining was seen in inflamed, atrophic crypts (arrowheads) and in neighbouring intact epithelium (arrows, x10 obj). 

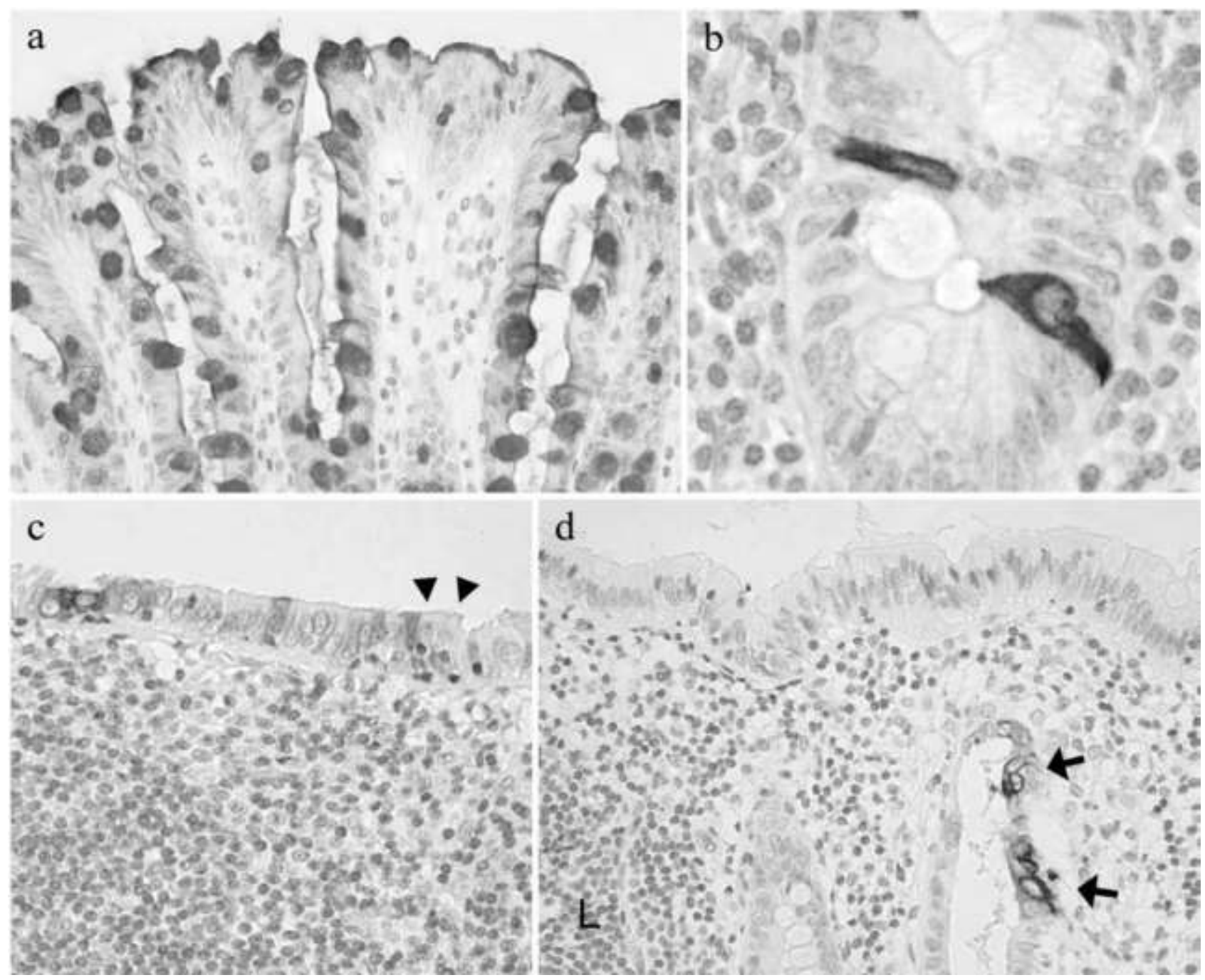

Figure 2. Cases of a-b) normal colorectum immunostained for CA19-9 and c-d) normal appendix immunostained for cytokeratin 7 (CK7). Diffuse goblet cell and apical membrane staining for CA19-9 is shown in a) (x20 obj) and b) occasional crypt epithelial cells showing cytoplasmic CA19-9 expression were seen away from lymphoid follicles (x40 obj). c) Focal CK7 expression was shown by cells in follicle associated epithelium but occasional cells with M cell morphology (arrowheads) lacked such expression (x20 obj). Further, d) occasional crypt epithelial cells (arrows) at a distance from lymphoid follicles (L) showed CK7 staining (x20 obj).

lymph node was used as a positive control for CD21 and CD23, a pancreatic adenocarcinoma as a positive control for CA19-9 and CK7, normal tonsil as

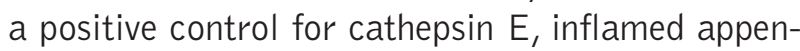
dix as a positive control for FcaR, and normal skin as a positive control for CDla and S100. Negative controls comprised sections incubated in antibody diluent (Dako) without primary antibody.

The immunostained sections were assessed by a gastrointestinal pathologist (NW). M cells were identified morphologically by their location in follicle associated epithelium, absence of a developed apical brush border, and the presence of lymphocytes in their basolateral compartments/pockets.

\section{Results \\ Cathepsin E}

Cathepsin E immunoreactivity was only seen in the cytoplasmic compartment. Such immunoreactivity was present in follicle associated epithelial cells in all 10 normal colorectal samples (Figure 1a) but only in 6/10 normal ileal samples and 7/10 normal appendiceal samples. Where present, up to $25 \%$ of follicle associated epithelial cells showed cathepsin E expression. Cathepsin E positive epithelial cells were occasionally seen in ileal villi distant from lymphoid follicles (4/10 ileal samples, Figure 1b) and in crypts unrelated to lymphoid tissue (4/10 appendiceal samples, Figure 1c), hereafter 
referred to as non-follicular villi and crypts, respectively. In the 10 normal colorectal samples studied, cathepsin $\mathrm{E}$ immunoreactivity was never seen in epithelium unrelated to lymphoid tissue; cathepsin E was occasionally expressed by cells lacking a classical M cell morphology but such cells were either located in the follicle associated epithelium or in crypt epithelium within lymphoid follicles (Figure 1a).

Two of the 3 microsatellite stable and 2 of the 3 microsatellite unstable colorectal carcinomas showed cathepsin E expression (Figure $1 d$ ). The staining was focal in all 4 cases and, in one tumour, was limited to its mucinous component. Cathepsin E expression was seen in 7/8 colorectal adenomas (Figure 1e) and $4 / 5$ hyperplastic/metaplastic polyps (Figure If). Staining was focal in all the positive cases and, amongst the adenomas, was predominantly found in the superficial epithelium (Figure 1e). Four of the 5 cases of active ulcerative colitis showed cathepsin E expression (Figure $1 \mathrm{~g}$ ). This expression was focal and present both in surface and crypt epithelium. Focal cathepsin E expression was present in $4 / 5$ cases of pseudomembranous colitis, both in atrophic crypts and epithelium adjacent to ulceration (Figure Ih). Cathepsin $E$ staining was not seen in any of the cases of lymphocytic colitis or of collagenous colitis.

\section{CA19-9 (sialyl Lewis A)}

Diffuse immunoreactivity was present in goblet cell contents and along epithelial cell apical membranes in all 10 normal ileal samples, 3/10 normal appendiceal samples and $1 / 10$ normal colorectal samples (Figure 2a). Cytoplasmic immunoreactivity was seen in scattered epithelial cells within normal ileal, appendiceal and colorectal crypts, including those at a distance from lymphoid follicles (Figure 2b). Because of the diffuse nature of CA199 immunoreactivity in the ileal specimens, no differences in staining pattern were evident between $\mathrm{M}$ cells and enterocytes. M cells lacking immunoreactivity for CA19-9 were readily identified in the normal appendiceal and colorectal cases.

\section{CK7}

Where present, CK7 expression was seen along cell membranes and in the cytoplasm. CK7 was expressed by occasional epithelial cells within normal appendiceal follicle associated epithelium (Figure 2C). However, several appendiceal M cells lacked CK7 immunoreactivity (Figure 2c), and occasional CK7-positive epithelial cells were also present within non-follicular crypts in the appendix (Figure $2 \mathrm{~d}$ ). CK7 was not expressed by follicle associated epithelium or follicular crypt epithelium of normal ileum or colorectum.

\section{Other markers}

FcaR, S100, CD1a, CD21 and CD23 were not expressed in follicle associated epithelium or follicular crypt epithelium in any of the normal ileal, appendiceal or colorectal cases studied.

\section{Discussion}

We have investigated a wide range of potential specific markers for human intestinal M cells. A potential criticism of our study is its lack of ultrastructural analyses, which remain the gold standard for the identification of M cells within follicle associated epithelium (Jepson et al. 1998). In the cases of CA19-9 and CK7, however, their expression in non-follicular crypts and/or villi refuted the specificity of these potential markers; precise identification of $M$ cells in follicle associated epithelium was therefore irrelevant. A similar argument applied to cathepsin $\mathrm{E}$ in the normal appendix, normal ileum and diseased colorectum. Finally, the presence of cathepsin E in follicular crypt epithelium of normal colorectum and in a greater proportion of colorectal follicle associated epithelial cells than would be expected, i.e. 10\% (Jepson et al. 1998), indicated the marker was not specific to $M$ cells within these compartments. All our conclusions were, therefore, robust and did not require confirmation with ultrastructural analyses.

We have found cathepsin $E$ to be a specific marker of follicle associated epithelium and follicular crypt epithelium in the normal colorectum but not in the ileum or appendix. These findings mirror the regional specificity of several animal $\mathrm{M}$ cell markers (Table 1). The nature of the non-follicular, cathepsin E positive cells in ileal and appendiceal epithelium is uncertain. However, Finzi and colleagues have described similar cells in the ileum and suggest they represent cup cells (Finzi et al. 1993) which, like M cells, may be involved in the transportation of antigens and microbes across the intestinal epithelium (Madara et al. 1985). The presence of cathepsin $E$ in cells that handle antigen is in keeping with a potential role for the protease in antigen processing (Bennet et al. 1992). Such a 
role may explain our observation of more widespread epithelial expression of cathepsin $E$ in inflammatory conditions such as active ulcerative colitis and pseudomembranous colitis. This expression could be a non-specific response to acute inflammation and ulceration per se rather than being specific to these disease entities. Absence of cathepsin E expression in lymphocytic colitis would certainly be consistent with such expression being related only to acute inflammation. We had also been interested to see whether an M cell marker might be overexpressed in lymphocytic colitis because previous in vitro studies suggest lymphocytes may induce $\mathrm{M}$ cell differentiation in intestinal epithelial cells (Gullberg et al. 2000). Our negative findings, however, should only be cautiously compared with the in vitro data as T lymphocytes are the predominant cell found in lymphocytic colitis whereas a neoplastic B cell line was used in the co-culture experiments (Gullberg et al. 2000).

To the best of our knowledge, cathepsin E expression in neoplastic colorectal tissue has not been previously described. As mentioned earlier, Jass and colleagues have recently described a subtype of colorectal carcinoma which is thought to derive from follicle associated epithelium (Clouston et al. 2000, Jass et al. 2000). At least two factors, however, make it unlikely that the cathepsin $\mathrm{E}$ expression we observed in 4 carcinomas was due to such a derivation. First, none of these 4 carcinomas showed the distinctive morphological features (e.g. prominent lymphoid infiltrate) of Jass's follicle associated epithelium-derived colorectal carcinomas (Clouston et al. 2000, Jass et al. 2000). Second, none of Jass's carcinomas appeared to derive from pre-existing adenoma (Clouston et al. 2000, Jass et al. 2000); the expression of cathepsin $E$ in our sporadic colorectal adenomas therefore suggests such expression to be a feature of the 'standard' adenoma-carcinoma sequence rather than a unique pathway involving follicle associated epithelium. The presence of cathep$\sin E$ in hyperplastic/metaplastic polyps is in keeping with the gastric-like phenotype shown by these polyps (Yao et al. 1999) and the normal expression of the protease in gastric foveolar epithelium (Samloff et al. 1987).

As mentioned above, the presence of cathepsin $E$ in $\mathrm{M}$ cells would be in keeping with possible roles in antigen processing and presentation. In spite of such roles, we failed to apply markers of other antigen presenting cells to M cells or follicle associat- ed epithelium as a whole. We also failed to utilise the fact that IgA binds specifically to $M$ cells (Weltzin et al. 1989) to find a specific marker for these cells. The receptor for IgA on M cells therefore remains unknown. Despite initial promising findings, non-follicular epithelial expression of $\mathrm{CK} 7$ precluded its use as a specific marker for appendiceal $M$ cells. That a previous study failed to show any expression of CK7 at all in appendiceal mucosa may be due to the authors' use of frozen tissue immunohistochemistry and a different antibody (Kucharzik et al. 1998). Again, use of a different antibody might explain our failure to confirm the findings of Giannasca and colleagues that sialyl Lewis $A$ is a specific marker of human $M$ cells (Giannasca et al. 1999).

In summary, of a large panel of markers tested, only cathepsin E was found to be specific to follicle associated epithelium and follicular crypt epithelium. However, this specificity was restricted to normal colorectum and the marker did not distinguish between $M$ cells and other follicle associated epithelial or follicular crypt epithelial cells. Our study has shown, for the first time, that cathepsin E expression is aberrantly expressed both in actively inflamed and in neoplastic colorectal epithelium. The pathophysiological significance of these preliminary findings will require further study.

\section{Acknowledgements}

We thank Professor Benjamin Chain for his advice regarding the study of cathepsin $E$, and $D r$ Bryan Warren for reviewing the manuscript.

\section{References}

Allen DC, Foster $\mathrm{H}$, Orchin JC, Biggart JD. Immunohistochemical staining of colorectal tissues with monoclonal antibodies to ras oncogene p21 product and carbohydrate determinant antigen 19-9. J Clin Pathol 1987;40:157-62.

Bennet K, Levine T, Ellis JS, Peanaski RJ, Samloff IM, Kay J, et al. Antigen processing for presentation by class II major histocompatibility complex requires cleavage by cathepsin E. Eur J Immunol 1992;22:1519-24.

Clark MA, Jepson MA, Simmons NL, Booth TA, Hirst BA. Differential expression of lectin-binding sites defines mouse intestinal M-cells. J Histochem Cytochem 1993;41:1679-87.

Clark MA, Hirst BA, Jepson MA. M-cell surface beta 1 integrin expression and invasin-mediated targeting of Yersinia pseudotuberculosis to mouse Peyer's patch M cells. Infect Immunol 1998;66:1237-43.

Clouston AD, Clouston DR, Jass JR. Adenocarcinoma of colon differentiating as dome epithelium of gut-associated lymphoid tissue. Histopathology 2000;37:567.

Finzi G, Cornaggia M, Capella C, Fiocca R, Bosi F, Solcia E, et al. Cathepsin $E$ in follicle associated epithelium of intestine and tonsil: localization to $\mathrm{M}$ cells and possible role in antigen processing. Histochemistry 1993;99:201-11.

Gebert A, Rothkotter HJ, Pabst R. Cytokeratin 18 is an M-cell mark- 
er in porcine Peyer's patches. Cell Tiss Res 1994;276:213-21.

Giannasca PJ, Giannasca KT, Leichtner AM, Neutra MR. Human intestinal $M$ cells display the sialyl Lewis $A$ antigen. Infect Immun 1999;67:946-53.

Gullberg E, Leonard M, Karlsson J, Hopkins AM, Brayden D, Baird AW, et al. Expression of specific markers and particle transport in a new human intestinal M-cell model. Biochem Biophys Res Comm 2000;279:808-13.

Jarry A, Vallette G, Cassagnau E, Moreau A, Bou-Hanna C, Lemarre $P$, et al. Interleukin 1 and interleukin lbeta converting enzyme (caspase 1) expression in the human colonic epithelial barrier. Caspase 1 downregulation in colon cancer. Gut 1999;45:246-51.

Jass JR, Constable L, Sutherland R, Winteford CM, Walsh MD, Young $J$, et al. Adenocarcinoma of colon differentiating as dome epithelium of gut-associated lymphoid tissue. Histopathology 2000;36: 116-20.

Jepson MA, Mason CM, Bennett MK, Simmons NL, Hirst BH. Coexpression of vimentin and cytokeratins in $\mathrm{M}$ cells of rabbit intestinal lymphoid follicle-associated epithelium. Histochemical J 1992; 24:33-9.

Jepson MA, Clark MA. Studying M cells and their role in infection. Trends Microbiol 1998;6:359-65.

Kerneis S, Bogdanova A, Colucci-Guyon E, Kraehenbuhl JP, Pringault E. Cytosolic distribution of villin in $\mathrm{M}$ cells from mouse Peyer's patches correlates with the absence of a brush border. Gastroenterology 1996;110:515-21.

Kitamura T, Garofalo RP, Kamijo A, Hammond DK, Oka JA, Caflisch $C R$, et al.Human intestinal epithelial cells express a novel receptor for IgA. J Immunol 2000;164:5029-34.

Kucharzik T, Lugering N, Schmid KW, Schmidt MA, Stoll R, Domschke W. Human intestinal $M$ cells exhibit enterocyte-like intermediate filaments. Gut 1998;42:54-62.

Madara JL, Carlson SL. Cup cells: further structural characterization of the brush border and the suggestion that they may serve as an attachment site for an unidentified bacillus in guinea pig ileum. Gastroenterology 1985;89:1374-86.

Maurer CA, Friess $H$, Kretschmann B, Wildi S, Muller C, Graber $H$, et al. Over-expression of ICAM-1, VCAM-1 and ELAM-1 might influence tumor progression in colorectal cancer. Int $\mathrm{J}$ Cancer 1998; 79:76-81.

Morton HC, Schiel AE, Janssen SW, van de Winkel JG. Structure and function of human IgA Fc receptors (Fc $\alpha R$ ). Crit Rev Immunol 1996;16:423-40.

Mu JZ, Gordon M, Shao JS, Alpers DH. Apical expression of func- tional asialoglycoprotein receptor in the human intestinal cell line HT-29. Gastroenterology 1997;113:1501-9.

Nagura $H$, Ohtani $H$, Masuda T, Kimura M, Nakamura S. HLA-DR expression on M cells overlying Peyer's patches is a common feature of human small intestine. Acta Pathol Jpn 1991;41:818-23.

Neutra MR. Current concepts in mucosal immunity. $V$ Role of M cells in transepithelial transport of antigens and pathogens to the mucosal immune system. Am J Physiol 1998;274:G785-91.

Nicoletti C. Unsolved mysteries of intestinal M cells. Gut 2000; 47: 735-9.

Osborn M, van Lessen G, Weber K, Kloppel G, Altmannsberger M. Differential diagnosis of gastrointestinal carcinomas by using monoclonal antibodies specific for individual keratin polypeptides. Lab Inv 1986;55:497-504.

Pappo J, Mahlman RT. Follicle epithelial M cells are a source of interleukin-1 in Peyer's patches. Immunology 1993;78:505-7.

Rautenberg K, Cichon C, Heyer G, Demel M, Schmidt MA. Immunocytochemical characterization of the follicle-associated epithelium of Peyer's patches: anti-cytokeratin 8 antibody (clone 4.1.18) as a molecular marker for rat M cells. Eur J Cell Biol 1996; 71:363-70.

Samloff IM, Taggart RT, Shiraishi T, Branch T, Reid WA, Heath R, et al. Slow moving proteinase. Isolation, characterization and immunohistochemical localization in gastric mucosa. Gastroenterology 1987; 93:77-84.

Shimono R, Mori M, Akazawa K, Adachi $Y$, Sgimachi K. Immunohistochemical expression of carbohydrate antigen 19-9 in colorectal carcinoma. Am J Gastroenterol 1994;89:101-5.

Shmakov AN, Ghosh S. Prion proteins and the gut: une liaison dangereuse? Gut 2001;48:443-7.

Spencer J, Finn T, Isaacson PG. Expression of HLA-DR antigens on epithelium associated with lymphoid tissue in the gastrointestinal tract. Gut 1986;27:153-7.

West AB, Isaac CA, Carboni JM, Morrow JS, Mooseker MS, Barwick $\mathrm{KW}$. Localization of villin, a cytoskeletal protein specific to microvilli, in human ileum and colon and in colonic neoplasms. Gastroenterology 1988;94:343-52.

Weltzin R, Lucia-Jandris $P$, Michetti P, Fields BN, Kraehenbuhl JP, Neutra MR. Binding and transepithelial transport of immunoglobulins by intestinal $\mathrm{M}$ cells: demonstration using monoclonal IgA antibodies against enteric viral proteins. J Cell Biol 1989;108:1673-85.

Yao T, Kouzuki T, Kajiwara M, Matsui N, Oya M, Tsuneyoshi M. 'Serrated' adenoma of the colorectum, with reference to its gastric differentiation and its malignant potential. J Pathol 1999;187:5117 . 